\title{
Reform Analysis of Teaching Methods in Teaching-based Colleges and Universities for Employment Promotion
}

\author{
Jing Xian \\ Shaanxi Institute of International Trade \& Commerce; Xi'an 712046 China
}

Keywords: employment rate; teaching-based college; teaching methods

\begin{abstract}
The homogenization trend of college education makes the college teaching pattern which aims at raising employment rate become one of the most important trends in the transition of higher education. At the same time, the methods and concepts of higher education have a direct impact on the quality of personnel training. This paper focused on the study and analysis of teaching-based colleges and universities. On the basis of deeply grasping the characteristics of teaching-based colleges in aspects, such as the purpose of running a school, the quality of students and the teaching philosophy, the author also analyzed the current problems of the employment-oriented teaching like the uncompleted system and untargeted teaching practice, and then put forward corresponding countermeasures, hoping to improve the teaching quality of teaching-based colleges and universities and support them train more capable students for the society.
\end{abstract}

\section{Introduction}

It has been the fact that the students who are cultivated by teaching-based colleges and universities are high quality and comprehensive talents with good social practical ability who can meet social practical needs. However, due to the fact that the traditional education system in China cannot adapt to the market-oriented training mode quickly, there is not enough attention given to students' practical ability and employment-oriented teaching in the actual teaching process. Therefore, in the actual teaching process, it is the main direction of the future development of classroom teaching in teachingbased colleges and universities to make clear the employment orientation and improve students' operating ability, which also provides a realistic basis for this study.

\section{Current problems of classroom teaching in the teaching-based colleges and universities}

Due to the influence of the training mode of traditional higher education, although importance is attached to the simultaneous teaching of basic knowledge and basic skills in the process of training at present, there are still some problems in the comprehensive application. These problems are interrelated with the current education system and the level of socio-economic development and also have certain historic features. However, with the full implementation of ability-oriented and practiceoriented teaching methods, the society poses increasing demand for high-level specialists and increasingly high requirements on their abilities. This has led to some problems in personnel training in colleges and universities, shown as follows:

\subsection{Uncompleted employment-oriented teaching system}

The lack of employment-oriented teaching system theory in higher education in China is an important factor for problems in the overall teaching and related imperfect teaching practice. The theory system has very important guiding significance for teaching practice, because a set of mature and well-established teaching theories can better serve the corresponding teaching work ${ }^{1}$. The lack of a corresponding employment-oriented teaching system is the primary factor that leads to the ignorance of the development of students' personal development and professional ability in the actual teaching process, generating non-systematic teaching rules. This kind of teaching cannot adapt to requirements of the economic development on high-quality personnel, so that it is difficult for college students to deal with the job and the specific work arrangements, resulting in limitations of talent development. Secondly, the employment-oriented teaching system lacks a unified and standardized management plan. Because of the conflict between the current higher education system and the 
corresponding employment-oriented teaching reform, most schools lack a unified teaching system for reference. Faced with a wide variety of majors, the current management system often loses its efficiency and flexibility, which may result in greater problems in the corresponding teaching sessions.

\subsection{Untargeted teaching practice}

The teaching method combining the theory with practice is the supplementary means for teaching which closely combines with the specific teaching purposes. Practice plays an important role in the undergraduates' mastery of professional disciplines and their professional competence. At present, there are various problems in China's teaching-based colleges and universities, such as ignorance of cultivation of high-quality practical ability, lack of practical requirements for specialized courses, few hours and low standards for practical activities, lack of effective guidance and targeted explanations ${ }^{2}$.This has led to the fact that most students keep a perfunctory attitude to the subjects emphasizing practical ability and experience, which greatly weakens the purpose that higher education practice teaching should achieve. In this context, students' understanding of the development remains at the stage of learning related theories and listening to teachers' explanations of specific cases. They do not connect it with their own behaviors and realistic development. This is also a major problem of the teaching methods in China's higher education which emphasizes the promotion of employment rate.

\section{Relevant measures for the efficient conversion of classroom teaching in teaching-based colleges and universities}

\subsection{Identifying the demand and training objective of students' professionalism}

In order to promoting the innovation of the training mode of talents, it is necessary to determine the training objectives of related majors and formulate specific teaching plans in teaching-based colleges and universities.

First of all, it is important to make clear the significance of different majors for the modern economic society. For example, in the actual management of an enterprise, economic management mainly monitors the use and distribution of property, business inventories and actual resource consumption and profitability, and prepares the enterprise's financial statement according to the relevant changes and balance. Economic management also needs to make a comprehensive analysis and reporting on the assets and liabilities of the enterprise, the cash flow, the profit situation and the shareholders' income, it also needs to pass the relevant financial indicators analysis when necessary. In general, economic management has a direct meaning and effect on the business status of an enterprise. Therefore, in the training of professional personnel should pay more attention to the direction of social needs to achieve targeted adjustments of teaching direction ${ }^{3}$.

Secondly, it is necessary to clarify the difference between the cultivation of professional personnel and the training of general talents. This difference is reflected in many aspects such as the career goals, teaching levels, the proportion of practice and theoretical teaching. Recognizing the existence of this difference can help to reform the teaching concepts and methods of current problems in colleges and universities by corresponding measures, such as using teaching materials more professional, increasing the proportion of practical operations and reducing the proportion of teachers' teaching contents. In this way, college education will take students as the main body in the classroom teaching, helping them find career plans and corresponding points of interest in economic management courses.

\subsection{Cultivating high-quality technical personnel and forming the application model "professionalism + Internet talents"}

Internet resources have greatly enriched the education of talented people, and there seems to be no intersection between the education of IT talents and the one of traditional technical personnel. However, the most direct and effective way in the process of information transformation is to make overall planning and form professionals to cultivate various professional talents with the ability of applying Internet. This is mostly due to the fact that traditional professional and technical personnel often cannot show due professionalism when handling business through the Internet, and even leak and lose important information due to their negligence and incaution ${ }^{4}$.For the modern society, the ability of an enterprise's staff using the Internet relates to the enterprise's business assets, the 
allocation of human resources and the development status. This concerns the real value of college students in their future jobs, and therefore no negligence and incaution is allowed. This requires that teaching-based colleges and universities should apply and partly apply the cultivation strategy of high-quality IT personnel or in the training of talents in other specialized fields. Taking the Accounting Major, students should reflect the professional competence in various links, including the intelligent processing of accounting business, security encryption and data integration and analysis. At the same time, schools should regularly carry out information technology training to train and assess students' learning, so as to promote them to continue learning information technologies and combine them with their own professional skills. This can ensure that students can use Internet information system expertly to enhance their work efficiency in the future.

\subsection{Enhancing students' interest in learning in the combination of theory and practice}

Teaching and practice can be regarded as an organic combination. In order to realize students' mastery of subject knowledge, the current practical teaching system is more focused on the practical part, and it is needed to promote interest-based teaching based on individual students in order to achieve good teaching practice.

This requires schools to highlight and optimize the teaching development, effectively stimulate students' interest in learning and curiosity of things, which will be an effective way to form basic professionalism, develop professional ability and stimulate innovation. In teaching, it is very important to set up specialized courses according to the comprehensive needs of future occupations and positions, embody the frontier of professional teaching development and ensure that teaching theories are updated in real time and practice skills are often practiced. At the same time, in order to guide students' interests, schools can set up interest teaching classes according to schools' own positioning and the investigation of the students' actual interest in learning. It is feasible to construct high-quality excellent courses and extend them the whole university to achieve the overall quality improvement of students.

In the traditional teaching, teachers tend to focus on the explanation and analysis of tedious professional knowledge, and expect that the students are able to form practical ability and professional quality through the understanding of the topics. But this kind of teaching methods, to a large extent, neglects the student's own ideas and also make the subject practice based on the reality become the mission appointed by teachers. The application of the innovative teaching methods above can better reflect the education demand in the new era and achieve the improvement of education level.

\subsection{Setting up learning group for specialized courses and standardizing interactive teaching}

The interaction between teachers and students and between students should follow the original development goal of specialized education in teaching-based colleges and universities. Any teaching method is undesirable if it deviates from teaching practice and disregards teaching content, which further illustrates the importance of efficient classroom ${ }^{5}$.Therefore, it is necessary to strengthen the construction of study groups of different majors, and the construction of study groups of such kind are of great significance for the study and interaction of specialized elementary courses and practical courses. First of all, it achieves a better internal learning environment. In the past, most specialized education in colleges and universities cannot achieve effective actual teaching result, because it was carried out in the form of large-scale class teaching for dozens of students every time. Most students did not have a good understanding of how to combine theories with practices to improve their professional abilities, while teachers could not clearly understand the ideas of different students, and thereby there was a great shortcoming in the distribution of teaching information. The teaching team can limit the number of members and implement education by students themselves under the lead of the class committee. Specific interaction patterns can be taken based on specific learning content. The interaction between acquaintances will continue to repeat among familiar objects in a familiar language environment for specific purposes, making the students continue strengthening their inherent sense of learning. Led by this deeply integrated teaching mechanism, more and more students will feel that the practice form of their professional study can better purify their minds and deepen their ideas, which in turn help them to choose learning mode more appropriate in specific occasions. Moreover, it is also more conducive to the realization of humanistic education. The interaction in the 
group makes the students' viewpoints and opinions can be criticized and reflected as fully as possible, so as to enable them to get a guiding conclusion.

In addition, teachers play an important role in perfecting employment-oriented higher education, which requires teachers to strengthen daily teaching learning and further study teaching methods based on different professional requirements and innovations in employment-oriented education. For example, teachers can join the teaching system of multimedia teaching and multi-method teaching, improve the guidance to students in the process of teaching and guide them to fundamentally enhance the cognition and further study of personnel training mode in employment-oriented colleges and universities.

\section{Conclusion}

To sum up, as a pillar-type force for market and service economy construction, teaching-based colleges and universities must synchronize the cultivation of students' abilities and improvement of students' knowledge and cultural quality, and this has been reflected in the core requirements of innovative personnel training mode. To this end, targeted changes are needed in the structure of practical teaching and teaching modules. After studying the framework of an effective way for the cultivation of college students with good professional qualifications and full professional competence, the author put forward that it is an important way to enhance the effectiveness of teaching in teachingbased colleges and universities by perfecting the classroom teaching based on the goal of improving employment rate. It is of great significance to improve the training mode of applied talents in colleges and universities and to transport more capable modernized talents to the related industries in China. The research in this paper can provide better reference for related teaching-based colleges and universities and help them to highlight "application" and "practical ability training" in the formulation of practical teaching framework, so as to promote the employment rate of students.

\section{Acknowledgments}

The Project of Shaanxi Education Planning Office:" Study on the effectiveness of teaching in teaching-oriented college” (No. SGH13503)

\section{References}

[1] Ji Xiaoli. Flexible Application of Diversified Teaching Methods in Colleges and Universities -Based on the Perspective of the Reform of Teaching Methods of International Shipping Business Management [J]. Journal of Taiyuan Urban Vocational College, 2017 (05): 144-145.

[2] Xiao Haixia. The Reform of Class Teaching Methods for Applied Talents Cultivation in Local Colleges and Universities [J]. Anhui Literature, 2017 (03): 124-126.

[3] Cao Huanjun. Research on the Effect of Application-oriented Teaching Method Reform in Art Design Major in Chinese Universities [J]. Courses Education Research, 2013 (13): 23-24.

[4] Xie Ting. The Cultivation of Compound Foreign Language Talents for Business English in the Context of "Belt and Road" [J]. Science and Technology, 2017, (23): 196-197.

[5] Zhang Guojian. Research on Language Skills Cultivation of Cross-border E-commerce English Talents under the "Belt and Road" --A Case Study in Xi'an [J].Economic Research Guide, 2017, (09): 133-135 